Original Research Paper

\title{
The Effect of Adding Iodine to the Feed to Increase Growth and Survival Rate of Carp Seeds (Cyprinus carpio)
}

\author{
Ayu Nirmaniar Fadliani ${ }^{1 *}$, Ayu Adhita Damayanti ${ }^{1}$, Ibadur Rahman ${ }^{1}$ \\ ${ }^{1}$ Program Studi Budidaya Perairan, Universitas Mataram, Mataram, Indonesia;
}

\author{
Article History \\ Received : February $14^{\text {th }}, 2020$ \\ Revised : July $27^{\text {th }}, 2020$ \\ Accepted : August $05^{\text {th }}, 2020$ \\ Published : August $26^{\text {th }}, 2020$ \\ *Corresponding Author: \\ Ayu Nirmaniar Fadliani, \\ Program Studi Budidaya \\ Perairan, Universitas Mataram, \\ Mataram, Indonesia. \\ Email: \\ Nirmaniarayu@gmail.com
}

\begin{abstract}
One of the factors that greatly influence the successful growth of cultivated fish is feed. The aim of this study was to examine the effect of iodine addition on the growth and survival rate of carp (Cyprinus carpio) seeds. This study used a completely randomized design (CRD) method with 4 treatments and 3 replications. 10 fish per unit each, with treatment P0 (feed without adding iodine), P1 (feed + iodine at a dose of $10 \mathrm{mg} / \mathrm{kg}$ ), P2 (feed + iodine at a dose of $20 \mathrm{mg} / \mathrm{kg}$ ), P3 (feed + iodine at a dose of $30 \mathrm{mg} / \mathrm{kg}$ ). The results showed that there was no significant effect $(p>0.05)$ on the growth rate, feed conversion and survival rate of goldfish. So it can be concluded that the addition of iodine in feed supplementation up to a dose of $30 \mathrm{mg} / \mathrm{kg}$ does not have a significant effect on the growth rate of length and absolute weight, feed conversion, survival rate and iodine content in the body of goldfish (Cyprinus carpio). The best recommended dose of iodine for growth is $20 \mathrm{mg} / \mathrm{kg}$ of feed, although the results were not significantly different for growth. However, it can have an effect on the iodine content in the body of goldfish.
\end{abstract}

Keywords: iodine; growth; survival rate; Cyprinus carpio.

\section{Pendahuluan}

Ikan mas (Cyprinus carpio) adalah salah satu komoditas ikan air tawar yang sangat digemari oleh masyarakat baik untuk konsumsi maupun sebagai ikan hias. Pengembangan budidaya ikan mas akhir-akhir ini semakin mengalami peningkatan (Alminiah 2015).

Budidaya ikan mas memiliki peluang pengembangan budidaya besar untuk meraih potensi pasar yang terus meningkat dengan berbagai macam keuntungan seperti dapat membantu meningkatkan taraf hidup masyarakat, dapat pula memperluas lapangan pekerjaan dan dapat meningkatkan gizi masyarakat (Syafar et al., 2017).

Salah satu faktor yang sangat berpengaruh terhadap keberhasilan pertumbuhan ikan budidaya adalah pakan. Pemberian pakan yang tidak sesuai dengan kebutuhan ikan akan menyebabkan kelangsungan hidup dan pertumbuhan ikan menjadi terganggu.

Mineral yodium merupakan elemen non logam dan mikro nutrien penting yang sangat diperlukan tubuh dalam jumlah renik. Yodium tidak tersedia di dalam tubuh ikan secara alami, melainkan harus melalui serapan makanan atau minuman yang mengandung yodium. Pada ikan air tawar kandungan yodiumnya lebih rendah dibandingkan dengan ikan air laut. Kandungan yodium dalam ikan mas sendiri hanya sebesar $1,7 \mathrm{mg} / \mathrm{kg}$. Yodium sangat dibutuhkan untuk pertumbuhan dan kelangsungan hidup (Azmat, 2008).

Penelitian ini bertujuan untuk mengkaji pengaruh penambahan yodium terhadap pertumbuhan dan tingkat kelangsungan hidup benih ikan mas (Cyprinus carpio).

\section{Bahan dan Metode}

\section{Waktu dan Tempat}

Penelitian ini dilaksanakan pada bulan Maret hingga Agustus 2019 yang dilakukan di Instalasi Pribadi serta di Laboratorium Kimia dan Biokimia Fakultas Teknologi Pangan, Universitas Mataram. Ikan yang digunakan dalam penelitian ialah berupa ikan mas dengan berat rata - rata 5,46 g. Yodium yang digunakan untuk penambahan suplementasi pakan merupakan yodium murni yang diencerkan dengan larutan kalium iodida. Penelitian ini menggunakan metode eksperimental dengan pola Rancanagan Acak Lengkap (RAL) (Joerakate et al., 2003 dalam Wulandari, 2012) yang terdiri dari 4 perlakuan dan 3 ulangan sehingga diperoleh 
12 unit percobaan, dimana masing-masing wadah berisi 10 ekor ikan.

P0 : Pakan tanpa penambahan yodium (kontrol)

$\mathrm{P} 1$ : Pakan + yodium dengan dosis $10 \mathrm{mg} / \mathrm{kg}$ pakan

$\mathrm{P} 2$ : Pakan + yodium dengan dosis $20 \mathrm{mg} / \mathrm{kg}$ pakan

P3 : Pakan + yodium dengan dosis $30 \mathrm{mg} / \mathrm{kg}$ pakan

Parameter yang diamati dalam penelitian ini adalah laju pertumbuhan mutlak, nilai konversi pakan, tingkat kelangsungan hidup dan kandungan yodium pada ikan mas setelah dipelihara pakan selama jangka waktu tertentu selama perlakuan. Data yang diperoleh dianalisis menggunakan Analysis of Variance (ANOVA) dengan tingkat kesalahan 5\%. melalui program SPSS untuk mengetahui pengaruh dari setiap perlakuan.

\section{Hasil dan Pembahasan}

\section{Laju Pertumbuhan Mutlak}

Laju pertumbuhan mutlak berkaitan dengan pertambahan berat dan panjang tubuh ikan. Berdasarkan tabel analisis varians (ANOVA), didapatkan hasil yang menunjukkan bahwa penambahan yodium pada pakan memberikan hasil yang tidak berbeda nyata $(p>0,05)$ terhadap pertumbuhan panjang benih ikan mas, dimana penambahan dosis yodium hingga $30 \mathrm{mg} / \mathrm{kg}$ pakan masih belum optimal untuk meningkatkan pertumbuhan panjang benih ikan mas karena tidak ada kecenderungan terhadap pertumbuhannya. Hal ini diduga karena proses metabolisme setiap ikan berbeda - beda sehingga jumlah pakan yang diberikan lebih dominan digunakan untuk proses pencernaan, pergerakan, pernafasan, pematangan gonad, dibandingkan untuk proses pertumbuhan panjangnya. Pada penelitian ini tidak terlihat adanya korelasi antara pertumbuhan panjang dengan pertumbuhan berat, dikarenakan pertambahan panjang ikan mas baru dapat terlihat dalam rentang waktu yang lebih lama dibandingkan pertumbuhan beratnya. Adanya perbedaan pola pada diagram menunjukkan bahwa ikan mas memiliki pola allometrik positif, dimana pertumbuhan panjangnya lebih lambat dibandingkan dengan pertumbuhan beratnya. Wang et al. (2017) menyatakan bahwa konsentrasi penambahan mineral yang diperlukan oleh ikan harus tepat dan dapat mengoptimalkan aktivitas pencernaan ikan dengan baik sehingga penyerapan nutrisinya berjalan dengan maksimal. Pakan yang diberikan tambahan yodium dengan dosis yang sama belum tentu memiliki hasil pertumbuhan yang sama pula tergantung pada kondisi lingkungan, proses metabolisme, keadaan fisiologis serta yodium yang terkandung pada setiap jenis ikan, karena apabila yodium yang terkandung dalam tubuh ikan sudah tinggi, maka diduga ikan mas juga akan dapat merespon tambahan yodium yang diberikan dengan lebih baik.

Kebutuhan yodium dalam pakan sangat terbatas jumlahnya sehingga apabila terdapat kelebihan yodium yang dikonsumsi didalam tubuh ikan mas maka akan diekskresikan melalui urin. Data dari diagram pertumbuhan panjang menunjukan bahwa kecenderungan nilai rata - rata pertumbuhan panjang mutlak benih ikan mas terdapat pada P2 yaitu sebesar $0,53 \mathrm{~cm}$ selanjutnya diikuti oleh P3 sebesar 0,49 cm, P0 sebesar 0,47 cm, dan P1 sebesar 0,42 cm. Pertumbuhan panjang mutlak benih ikan mas dapat dilihat pada Gambar 4.

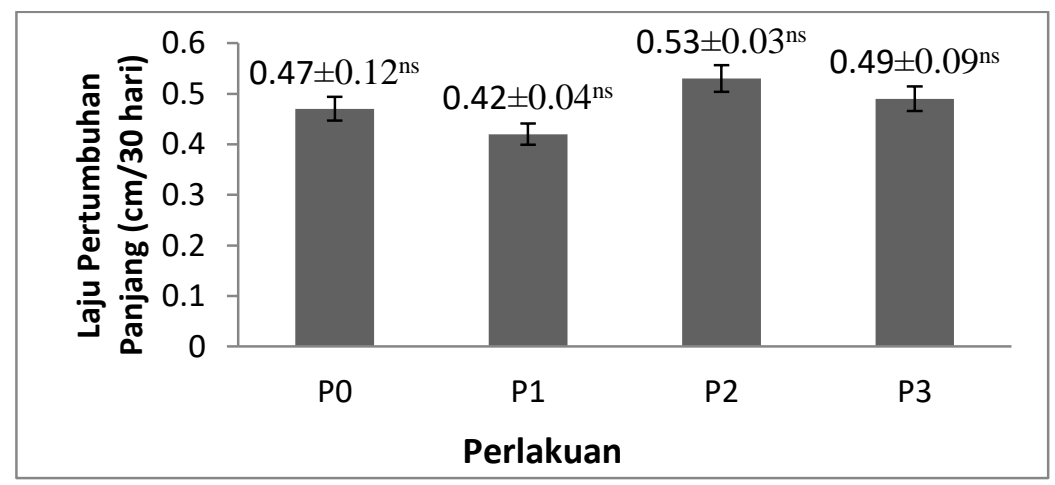

Gambar 4. Laju pertumbuhan panjang mutlak. (Keterangan P0: tanpa yodium, P1: 10 mg/kg pakan, $\mathrm{P} 2: 20 \mathrm{mg} / \mathrm{kg}$ pakan, dan $\mathrm{P} 3: 30 \mathrm{mg} / \mathrm{kg}$ pakan) 
Berdasarkan tabel analisis varians (ANOVA) didapatkan hasil yang menunjukkan bahwa penambahan yodium pada pakan memberikan hasil yang tidak berbeda nyata $(\mathrm{p}>0,05)$ terhadap pertumbuhan berat benih ikan mas. Menurut Franke et al. (2008) dalam Rehena (2018), apabila yodium diberikan dalam jumlah yang sesuai dengan kebutuhan tubuh maka akan mempengaruhi pertumbuhannya. Menurut Khalil et al. (2017) dalam Manurung (2017) yodium dapat diserap oleh tubuh dengan baik melalui proses metabolisme yaitu pakan yang sudah dicampur dengan yodium diubah menjadi iodida dan diserap oleh usus halus kemudian darah dialirkan menuju kelenjar thyroid. Dalam kelenjar thyroid yodium dioksidasi menjadi senyawa antar iod. Penggabungan oksidatif berikutnya dari yod ke dalam hormon thyroid membentuk hormon thyroksin (T4) dan triiodothyronin (T3), sehingga dapat merangsang laju oksidasi, mempengaruhi metabolisme, meningkatkan laju konsumsi oksigen, dan meningkatkan pertumbuhan.

Diagram pertumbuhan berat mutlak menunjukan bahwa kecenderungan nilai rata - rata pertumbuhan mutlak berat ikan mas terdapat pada P2 sebesar 1,03 g yang kemudian diikuti oleh P3 sebesar $0,90 \mathrm{~g}, \mathrm{P} 1$ sebesar $0,71 \mathrm{~g}$, dan P0 sebesar 0,58 g. Laju pertumbuhan berat mutlak ikan mas dapat dilihat pada diagram Gambar 5.

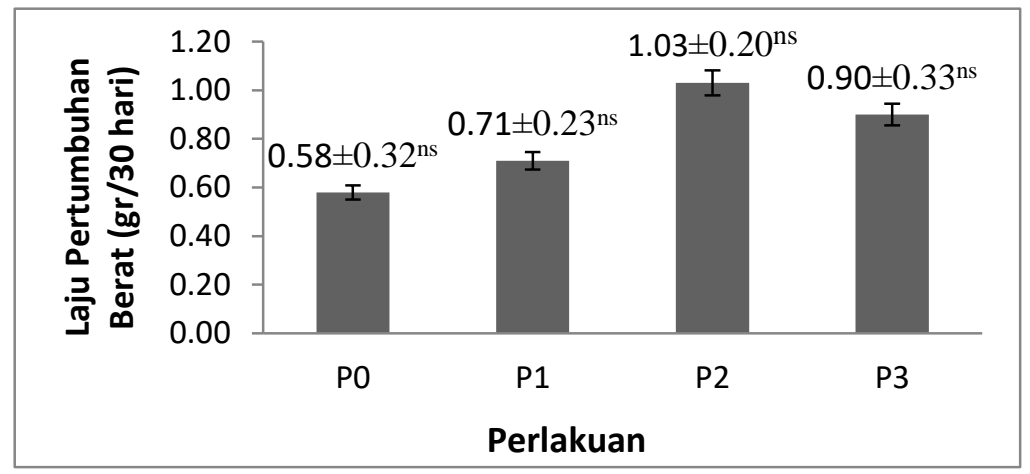

Gambar 5. Laju pertumbuhan berat mutlak. (Keterangan P0: pakan tanpa yodium, P1: $10 \mathrm{mg} / \mathrm{kg}$ pakan, $\mathrm{P} 2: 20 \mathrm{mg} / \mathrm{kg}$ pakan, dan $\mathrm{P} 3: 30 \mathrm{mg} / \mathrm{kg}$ pakan)

\section{Konversi Pakan}

Konversi pakan merupakan perbandingan jumlah pakan yang diberikan selama masa pemeliharaan. Berdasarkan tabel analisis varians (ANOVA) didapatkan hasil nilai rata - rata konversi pakan yang menunjukkan bahwa penambahan yodium pada pakan memberikan hasil yang tidak berbeda nyata $(p>0,05)$ terhadap nilai konversi pakan benih ikan mas. Menurut Putri et al. (2012) rasio konversi pakan berkaitan erat dengan kualitas pakan yang diberikan, dimana semakin rendah nilai konversi pakan maka semakin baik kualitas pakan yang diberikan. Selain itu nilai yang semakin rendah juga menunjukkan bahwa suplementasi pakan dapat dimanfaatkan oleh tubuh dengan baik.

Dari diagram Gambar 6 diketahui bahwa perlakuan dengan nilai konversi pakan terendah ialah pada P2 sebesar 8,5 selanjutnya P3 sebesar 10,3 kemudian P1 sebesar 14,3 dan P0 sebesar 15,7. Hal ini menunjukkan bahwa P2 dengan dosis yodium 20 $\mathrm{mg} / \mathrm{kg}$ pakan merupakan dosis yang optimal dalam memanfaatkan pakannya untuk meningkatkan pertumbuhan (EFSA, 2005).

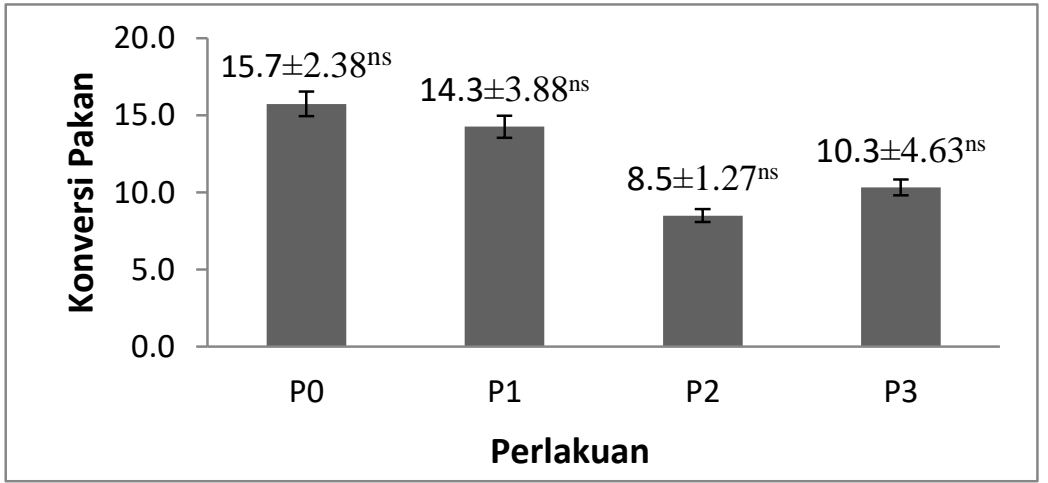

Gambar 6. Konversi pakan. (Keterangan P0: pakan tanpa yodium, P1: $10 \mathrm{mg} / \mathrm{kg}$ pakan, P2: $20 \mathrm{mg} / \mathrm{kg}$ pakan, dan P3: $30 \mathrm{mg} / \mathrm{kg}$ pakan)

Tingkat Kelangsungan Hidup 
Tingkat kelangsungan hidup merupakan jumlah ikan yang hidup di akhir pemeliharaan dibandingkan jumlah ikan awal pada saat penebaran dan disajikan dalam bentuk persentase (Effendie, 1979 dalam Rudiyanti, 2009). Berdasarkan tabel analisis kruskal menunjukan bahwa penambahan yodium pada pakan memberikan hasil yang tidak berbeda nyata $(\mathrm{p}>0,05)$ terhadap tingkat kelangsungan hidup benih ikan mas. Kematian ikan diduga karena masih dalam masa adaptasi, dan disebabkan karena ikan stres selama masa pemeliharaan. Menurut Marbun (2013) dalam Manurung (2017) kematian ikan dipengaruhi oleh beberapa faktor seperti kualitas air dan kondisi ikan tersebut. Kematian biasanya disebabkan karena pakan yang diberikan kurang bisa dimanfaatkan dengan baik. Menurut Simangunsong (2017) dalam Afdola (2018), tingkat kelangsungan hidup $\geq 50 \%$ tergolong baik, 30-50\% tergolong sedang dan untuk kelangsungan hidup $<30 \%$ dikatakan tidak baik.

Angka kelulushidupan ikan mas yang tertinggi terdapat pada perlakuan P2 dan P3 yaitu sebesar $100 \%$, kemudian P1 sebesar 96,67\% dan untuk angka kelulushidupan terendah terdapat pada perlakuan $\mathrm{P} 0$ yaitu $90 \%$. Nilai tingkat kelangsungan hidup benih ikan mas dapat dilihat pada diagram Gambar 7.

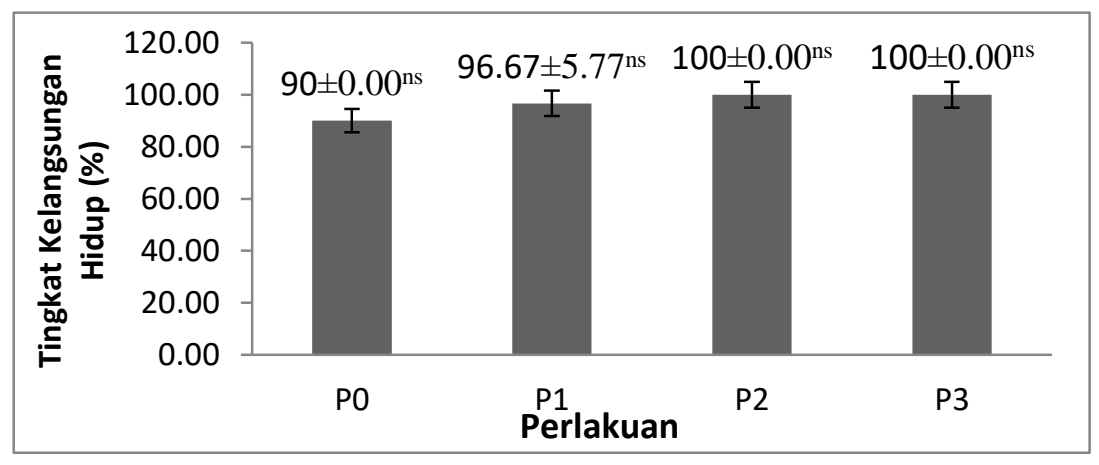

Gambar 7. Tingkat Kelangsungan Hidup. (Keterangan P0: pakan tanpa yodium, P1:10mg/kg pakan, P2: $20 \mathrm{mg} / \mathrm{kg}$ pakan, dan P3: $30 \mathrm{mg} / \mathrm{kg}$ pakan)

\section{Kandungan Yodium Pada Tubuh Ikan Mas}

Berdasarkan tabel kandungan yodium didapatkan hasil bahwa kandungan yodium benih ikan mas sebelum dipelihara yaitu sebesar 0,083 $\mathrm{mg} / \mathrm{kg}$ dan kandungan yodium benih ikan mas setelah dipelihara mengalami peningkatan yakni masing masing sebesar P0 : 0,091 mg/kg, P1 : 0,122 $\mathrm{mg} / \mathrm{kg}, \mathrm{P} 2: 0,145 \mathrm{mg} / \mathrm{kg}$ dan P3 : 0,126 mg/kg. Data hasil dari kandungan yodium benih ikan mas dapat dilihat pada diagram Gambar 8.

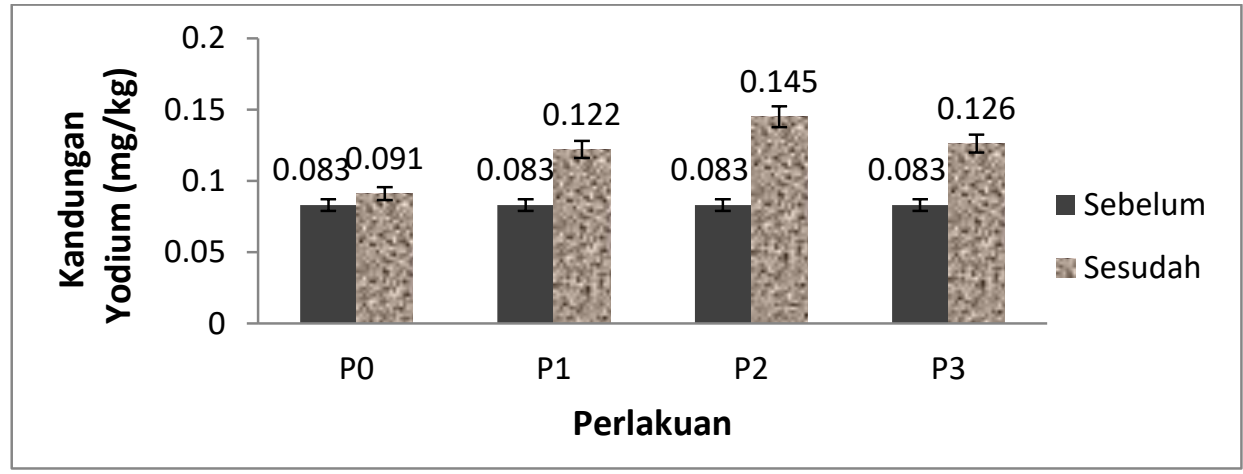

Gambar 8. Data kandungan yodium. (Keterangan P0: pakan tanpa yodium, P1: $10 \mathrm{mg} / \mathrm{kg}$ pakan, $\mathrm{P} 2: 20 \mathrm{mg} / \mathrm{kg}$ pakan, dan $\mathrm{P} 3: 30 \mathrm{mg} / \mathrm{kg}$ pakan)

Dari data tersebut menunjukan bahwa P2 memiliki hasil yang tertinggi, terjadinya peningkatan pada kandungan yodium menunjukkan bahwa pakan dapat diserap dan dimanfaatkan dengan baik untuk pertumbuhan ikan. Menurut Enggar (2013), ikan mas hanya memiliki kandungan yodium $1,7 \mathrm{mg} / \mathrm{kg}$. Rendahnya kadar yodium pada benih ikan mas diduga karena faktor lingkungan yang memiliki kadar yodium tanah dan air yang rendah. Pada penelitian lain dosis $20 \mathrm{mg} / \mathrm{kg}$ pakan sudah cukup untuk meningkatkan kandungan yodium. Hal ini dikarenakan setiap tempat memiliki kondisi perairan yang berbeda, sehingga jika kandungan yodium awal pada ikan sudah tinggi maka diduga ikan dapat lebih merespon tambahan yodium yang diberikan dengan lebih baik. Selain karena faktor perairannya, setiap ikan juga memiliki kandungan yodium yang berbeda didalam tubuhnya dan juga proses metabolism di dalam tubuh ikan juga di duga mempengaruhi kandungan yodium yang masuk kedalam tubuh ikan. 
Linder (1992) dalam Gunanti et al. (1999) menyatakan bahwa kadar yodium pada bahan makanan sangat bervariasi tergantung pada keadaan tanah, pupuk dan pengolahannya.

\section{Kualitas Air}

Beberapa variabel kualitas air yang diukur pada penelitian ini diantaranya yaitu: suhu, $\mathrm{pH}$, dan DO. Nilai rata - rata kualitas air dapat dilihat pada Tabel 4.

Tabel 4. Data Kualitas Air

\begin{tabular}{lllll}
\hline \multirow{2}{*}{ Parameter } & Perlakuan & P1 & P2 & P3 \\
\cline { 2 - 5 } Suhu $\left({ }^{\circ} \mathrm{C}\right)$ & $25-27$ & $25-27$ & $25-27$ & $25-27$ \\
$\mathrm{pH}$ & $7.2-7.8$ & $7.2-7.8$ & $7.3-7.8$ & $7.3-7.8$ \\
$\mathrm{DO}(\mathrm{mg} / \mathrm{l})$ & $3.4-4.4$ & $3.5-4.3$ & $3.4-4.2$ & $3.3-4.1$ \\
\hline
\end{tabular}

Berdasarkan tabel hasil pengukuran kualitas air di atas diperoleh nilai parameter suhu yang berkisar antara $25-27^{\circ} \mathrm{C}$. Hasil ini masih dikatakan baik dan optimal untuk kelangsungan hidup benih ikan mas. Menurut Santoso (1992) dalam Rudiyanti (2009) ikan mas mampu hidup pada suhu optimum yang berkisar antara $14-38^{\circ} \mathrm{C}$, sedangkan ikan mas tumbuh dengan baik pada suhu $23-30^{\circ} \mathrm{C}$ (Flajshans, 2007 dalam Syawal et al., 2012).

Nilai $\mathrm{pH}$ yang didapatkan pada penelitian berkisar antara 7,2-7,8. Dimana hasil ini masih dikatakan baik dan optimal untuk kelangsungan hidup benih ikan mas. Menurut Zonneveld et al. (1991) dalam Widiastuti (2009) $\mathrm{pH}$ air untuk kegiatan budidaya berkisar antara $6-9$.

Nilai DO pada penelitian berkisar antara 3,3 4,4 mg/l. Hasil ini masih dikatakan baik dan optimal untuk kelangsungan hidup benih ikan mas. Menurut Huet (1970) dalam Salmin (2005) idealnya kandungan oksigen terlarut dalam kegiatan budidaya tidak boleh kurang dari 1,7 mg/l dan kisaran yang optimal untuk oksgien terlarut dalam budidaya berkisar antara 4-10 mg/l.

\section{Kesimpulan}

Penambahan yodium pada suplementasi pakan hingga dosis $30 \mathrm{mg} / \mathrm{kg}$ tidak memberikan pengaruh yang berbeda nyata terhadap laju pertumbuhan panjang dan berat mutlak, konversi pakan, tingkat kelangsungan hidup serta kandungan yodium dalam tubuh ikan mas (Cyprinus carpio). Penelitian yang dilakukan ini adalah sebagai bentuk dari upaya mencari jawaban agar mendapatkan pengatahuan mengenai permasalahan dosis yodium yang paling tepat. Karena pada ikan yang kekurangan yodium dalam makanan dapat menyebabkan hypothyroid pada kelenjar thyroid. Dari hasil penelitian diatas dosis yodium yang direkomendasikan untuk suplementasi pakan ikan yaitu sebesar $10 \mathrm{mg} / \mathrm{kg}$ karena hasilnya yang tidak berbeda nyata maka dinilai lebih ekonomis.

\section{Ucapan terima kasih}

Terima kasih penulis ucapkan kepada kedua orang tua yang sudah mendukung hingga skripsi dan jurnal ini dapat terselesaikan dengan baik, terimakasih juga kepada ibu Adhita Ayu Damayanti S.Pi., M.Si dan bapak Ibadur Rahman S.Kel., M.Si selaku dosen pembimbing utama dan dosen pembimbing pendamping atas semua nasehat - nasehat dan bimbingannya.

\section{Referensi}

Agustono, A., \& Lamid, M. (2013). Pengaruh Pemberian Pakan Beryodium terhadap Pertumbuhan dan Kandungan Yodium Benih Ikan Mas (Cyprinus carpio)[Effect Of Iodized Feeding On The Growth And Content Of Iodine In Carpfish Seed (Cyprinus carpio)]. Jurnal Ilmiah Perikanan dan Kelautan, 5(1), 93-98. https://ejournal.unair.ac.id/JIPK/article/view/11431/6 $\underline{473}$

Alminiah, A. (2015). Pengendalian ektoparasit pada benih ikan mas (Cyprinus carpio L.) dengan penambahan garam dapur $(\mathrm{NaCl})$ di Balai Benih Perikanan Plalangan Kalisat Kabupaten Jember.

https://repository.unej.ac.id/handle/12345678 $\underline{9 / 65676}$

Azmat, R., Talat, R., \& Junaid Mahmood, S. (2008). Distribution of Iodine in Marine and Fresh Water Fishes from Sindh Regions of Pakistan. JApSc, 8(9), 1790-1792. https://ui.adsabs.harvard.edu/abs/2008JApSc.. .8.1790A/abstract

European Food Safety Authority (EFSA). (2005). Opinion of the Scientific Panel on additives 
and products or substances used in animal feed (FEEDAP) on the use of iodine in feedingstuffs. EFSA Journal, 3(2), 168. https://efsa.onlinelibrary.wiley.com/doi/abs/1 $\underline{0.2903 / \text { j.efsa. } 2005.168}$

Fajri, M. A., Adelina, A., \& Aryani, N. (2015). Penambahan Probiotik dalam Pakan terhadap Pertumbuhan dan Efisiensi Pakan Benih Ikan Baung (Hemibagrus Nemurus) (Doctoral dissertation, Riau University).

https://media.neliti.com/media/publications/2 00311-penambahan-probiotik-dalam-pakanterhada.pdf

Gunanti, I. R., Suhardjo, S., Kusharto, C. M., Rimbawan, R., \& Wirjatmadi, B. (1999). Kandungan Iodium pada Beberapa Bahan Makanan di Daerah Pantai Endemik dan Nonendemik. Buletin Penelitian Sistem Kesehatan, 3(1), 21033. https://www.neliti.com/publications/21033/ka ndungan-iodium-pada-beberapa-bahanmakanan-di-daerah-pantai-endemik-dan-nonen

Manurung, S., \& Basuki, F. (2017). PENGARUH LAMA PERENDAMAN HORMON TIROKSIN TERHADAP DAYA TETAS TELUR, PERTUMBUHAN, DAN KELANGSUNGAN HIDUP LARVA IKAN MAS KOKI (Carassius auratus). Journal of Aquaculture Management and Technology, 6(4), 202-211. https://ejournal3.undip.ac.id/index.php/jamt/a rticle/view/20563

Putri, F. S., Hasan, Z., \& Haetami, K. (2012). Pengaruh Pemberian Bakteri Probiotik Pada Pelet Yang Mengandung Kaliandra (calliandracalothyrsus) Terhadap Pertumbuhan Benihikan Nila (Oreochromis Niloticus). Jurnal Perikanan Kelautan, 3(4). http://jurnal.unpad.ac.id/jpk/article/view/2572

Rudiyanti, S., \& Dana, A. (2009). Pertumbuhan dan survival rate ikan mas (Cyprinus carpio Linn) pada berbagai konsentrasi pestisida regent 0,3 g. Saintek Perikanan, 5(1), 49-54. http://eprints.undip.ac.id/18959/

Salmin, O. T. (2005). dan Kebutuhan Oksigen Biologi (BOD) Sebagai Salah Satu Indikator Untuk Menentukan Kualitas Perairan. Pusat Penelitian Oseanogafi-Lipi, Jakarta.

Syafar, L. A., Mahasri, G., Rantam, F. A. (2017). Blood Description, Parasite Infestation and SurvivalRate of Carp (Cyprinus carpio) Which Is Exposed By Spore Protein Myxobolus koi On Rearing Pond As Immunostimulan Material. Jurnal Biosains Pascasarjana 19(2). http://garuda.ristekbrin.go.id/documents/detail $\underline{1734322}$

Syawal, H., Kusumorini, N., Manalu, W., \& Affandi, R. (2012). Respons fisiologis dan hematologis ikan mas (Cyprinus carpio) pada suhu media pemeliharaan yang berbeda. Iktiol. Indonesia, 12(1), 1-11. http://iktiologiindonesia.org/wpcontent/uploads/2016/07/JII_12_1_01.pdf

Wang, J., Dong, X., Shao, Y., Guo, H., Pan, L., Hui, W., ... \& Zhang, W. (2017). Genome adaptive evolution of Lactobacillus casei under longterm antibiotic selection pressures. BMC genomics, 18(1), 320. https://link.springer.com/article/10.1186/s128 $\underline{64-017-3710-\mathrm{X}}$

Widiastuti, I. M. (2009). Pertumbuhan dan kelangsungan hidup (survival rate) ikan mas (Cyprinus carpio) yang dipelihara dalam wadah terkontrol dengan padat penebaran yang berbeda. Media Litbang Sulteng, 2(2).

Wulandari, C. (2012). Pengaruh Pemberian Pakan Beryodium Terhadap Pertumbuhan Dan Kandungan Yodium Benih Ikan Mas (Cyprinus carpio). SKRIPSI. Program Studi Budidaya Perairan, Fakultas Perikanan dan Kelautan, Universitas Airlangga. 
Ayu Nirmaniar Fadliani et al. (2020). Jurnal Biologi Tropis, 20 (2): 314 - 319 DOI: http://dx.doi.org/10.29303/jbt.v20i2.1698 